\title{
Detection of 'Candidatus Phytoplasma pyri'in different pear tissues and sampling time by PCR-RFLP analyses
}

Farklı armut dokularında ve örnekleme zamanında 'Candidatus Phytoplasma pyri'nin PCR-RFLP analizleri ile saptanması

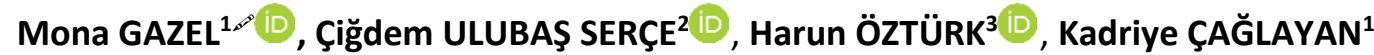

${ }^{1}$ Hatay Mustafa Kemal University, Faculty of Agriculture, Department of Plant Protection, Antakya-Hatay, Turkey.

${ }^{2}$ Niğde Ömer Halisdemir University, Faculty of Faculty of Agricultural Sciences and Technologies, Department of Plant Production and Technologies, Niğde, Turkey.

${ }^{3}$ Bursa Agricultural Quarantine Directorate, Bursa, Turkey.

\section{MAKALE BILGISI / ARTICLE INFO}

\section{Makale tarihçesi / Article history:}

DOI: $10.37908 /$ mkutbd.760581

Geliş tarihi /Received:30.06.2020

Kabul tarihi/Accepted:11.08.2020

\section{Keywords:}

Pear, flower, fruit, shoot, root, phytoplasma, PCR-RFLP.

\footnotetext{
Corresponding author: Mona GAZEL

$\bowtie$ : mhurigil@mku.edu.tr
}

\section{Ö ZET / A B S TR A C T}

\begin{abstract}
Aims: In this study, the best sampling time and tissues for phytoplasma detection in twenty pear trees (cv. Deveci) infected by 'Candidatus Phytoplasma pyri', causal agent of pear decline disease, in Bursa province of Turkey were investigated.

Methods and Results: Sampling was done throughout the year in leaf midribs, shoot and root tissues, where as the flower tissues were tested once a year in March and fruit tissues in September. All samples were analyzed by nested-PCR using P1/P7 and fU5/rU3 universal primer pairs. Nested PCR products were digested with Rsal and Sspl restriction enzymes. The results revealed that the detection rate of ' $\mathrm{Ca}$. P. pyri' in different plant tissues was greatly depending on the sample collection period. The fruit tissues, which were only sampled in September due to the ripening time of Deveci pear cultivar in Bursa, showed the highest detection rate of 'Ca. P. pyri' (100\%) followed by flower tissues (75\%). The average detection rate in root, shoot tissues and leaf midribs was found as 43.75, 39.58 and $16.25 \%$, respectively. The present results showed that the best plant tissues for detecting 'Ca. P. pyri' in pear trees were fruit columella and flowers. The highest detection rate of this phytoplasma in root tissues was found from November to March, whereas it could be detected whole year around except summer months in shoot samples in Turkey.

Conclusions: For 'Candidatus Phytoplasma pyri', detection, if there is no seasonal limitation for testing, the most suitable tissues are fruits and flowers. When it comes to testing throughout the year, the most suitable tissues were determined as the root, the phloem and cambium layer of the shoots and the leaves, respectively.

Significance and Impact of the Study: This study on seasonal variations of 'Candidatus Phytoplasma pyri' in different pear tissues has been first time investigated in Turkey. This preliminary data provides important knowledge on molecular detection of Ca. P. pyri, causal agent of pear decline disease for further studies and sertification-quarantine programmes of pear trees in Turkey.
\end{abstract}

Atıf / Citation: Gazel M, Ulubaş Serçe Ç, Öztürk, H, Çağlayan K (2020) Detection of 'Candidatus Phytoplasma pyri'in different pear tissues and sampling time by PCR-RFLP analyses. MKU. Tar. Bil. Derg. 25(3) : 406-412. DOI: 10.37908/mkutbd.760581 


\section{INTRODUCTION}

'Candidatus Phytoplasma pyri' the causal agent of pear decline (PD) belongs to the apple proliferation group (16SrX) (Seemüller and Schneider, 2004). It causes a serious disease in pear trees and is widespread in many pear growing countries of Europe, North America, Africa and Asia (OEPP/EPPO, 2007; Seemüller, 1989). The disease proceeds in two main ways as "slow" or "quick" decline. The most frequent is the slow decline typified by a suppression of shoot elongation and by small, pale green leaves that roll upward. In the autumn, the leaves may become orange-red and drop prematurely (Nemeth, 1986). The severity of PD varies widely depending on pear cultivar and the scion/rootstock combination (Seemüller et al., 1998). Pear decline phytoplasma was reported in the northeastern part of Turkey (Çağlayan et al., 2006) and the disease represented a serious outbreak with a $52.58 \%$ infection rate in various pear cultivars in Bursa province. Typical symptoms of disease such as reduced growth, leaf cupping and reddening, decrease fruit number and size were observed in different studies (Ulubas Serce et al., 2006; Gazel et al.,2007). PD was also detected in a small number of trees in Ankara and Yalova provinces using DAPI and molecular analyses (Canik and Ertunç, 2007). Phytoplasma detection has been improved by using molecular techniques based on PCR (Ahrens and Seemüller, 1992). Although the PCR techniques are very sensitive and reliable, sometimes it has failed due to uneven distribution, low concentration of the pathogen and the presence of inhibitors in plant tissue. The detection of PD in pear trees by PCR analyses could also vary based on the time of the year (Errea et al., 2002; Garcia-Chapa et al., 2003; Kucerova et al., 2007). In this study, different parts of infected trees such as shoots, leaf midribs, flowers, fruit columella, and roots were tested in different growing seasons all year around to find the most reliable plant tissues and the best season for the detection of PD in a local pear cultivar, Deveci in Bursa province of Turkey.

\section{MATERIALS and METHODS}

\section{Sample collection}

Twenty trees (cv. Deveci grafted on Pyrus communis rootstocks) from two PD infected orchards were sampled to investigate the seasonal detection of ' $\mathrm{Ca}$. P. pyri' in different plant tissues in Bursa province of Turkey. Severely PD infected trees, according to PCR analyses in previous study (Gazel et al., 2007), were selected for sampling. From each tree root, shoot and leaf midribs samples were collected from four sides of each tree all year around. However, flowers and fruit columellas from each tree were collected only in March and in September, respectively.

\section{DNA extraction}

Total nucleic acids from main leaf midribs, flowers, fruit columella, shoots and roots were extracted from $1 \mathrm{~g}$ of tissue using a chloroform/phenol procedure (Prince et al., 1993). Extracted DNA was dissolved in Tris-EDTA pH 8.0 buffer and maintained at $4{ }^{\circ} \mathrm{C} ; 20 \mathrm{ng} / \mu \mathrm{l}$ of nucleic acid were used for PCR amplification. Negative control of PCR tests consisted of reaction mixtures devoid of templates. Positive controls employed for the molecular analyses included DNA from phytoplasma reference strains maintained in periwinkle [Catharanthus roseus (L.) G. Don.] (Bertaccini et al., 2000).

\section{PCR-RFLP}

P1/P7 universal primers (Deng and Hiruki, 1991; Smart et al., 1996) located at the 16S rRNA genes were used in direct PCR and fU5/rU3 primers were used for nested PCR (Lorenz et al., 1995). PCR products were analyzed by electrophoresis through $1.2 \%$ agarose gel, stained with ethidium bromide and DNA bands were visualized using a UV transilluminator. Restriction fragment length polymorphism (RFLP) analysis of the amplified phytoplasmas $16 \mathrm{~S}$ rRNA gene fragments was performed with Rsal and Sspl (Fermentas, Vilnius, Lithuania) restriction enzymes and patterns were compared with phytoplasma reference strains.

\section{RESULTS and DISCUSSION}

In this study, different plant tissues such as root, shoot, leaf midribs, flower and fruit columella samples were collected from 'Ca. P. pyri' infected pear trees 'Deveci' in different periods to find out more reliable tissues and seasons for phytoplasma detection, and they were analysed by nested-PCR-RFLP (Fig. 1).

Root, shoot and leaf midribs were sampled all year around and average detection rate in two orchards by ' $C a$. P. pyri' in these tissues were $43.75,39.58$ and $16.25 \%$, respectively. The flowers were collected only in March and fruit columellas in September when these tissues were available. The average PD detection rates in fruit columellas and flowers were $100,75 \%$, respectively. The best period for testing of ' $\mathrm{Ca}$. P. pyri' both in root and shoot samples were winter months and the average detection rate in this season was found as $83.33 \%$ in roots and $63.33 \%$ in shoots. In these tissues it started to decrease in spring (38.33\% in roots, $43.33 \%$ in shoots), 
and autumn (36.66\% in roots and $41.66 \%$ in shoots) and reached to the lowest level in summer months $(16.66 \%$ in roots and $10.00 \%$ in shoots) (Table 1) (Fig. 2). The detection rate in leaf midribs, were collected from April to November, was also found lowest in summer (on average $10.00 \%$ ) and the highest in autumn (on average 23.33\%). In this study it was confirmed that ' $\mathrm{Ca}$. P. pyri' can be easily detected in different seasons all year around by using different tissues.
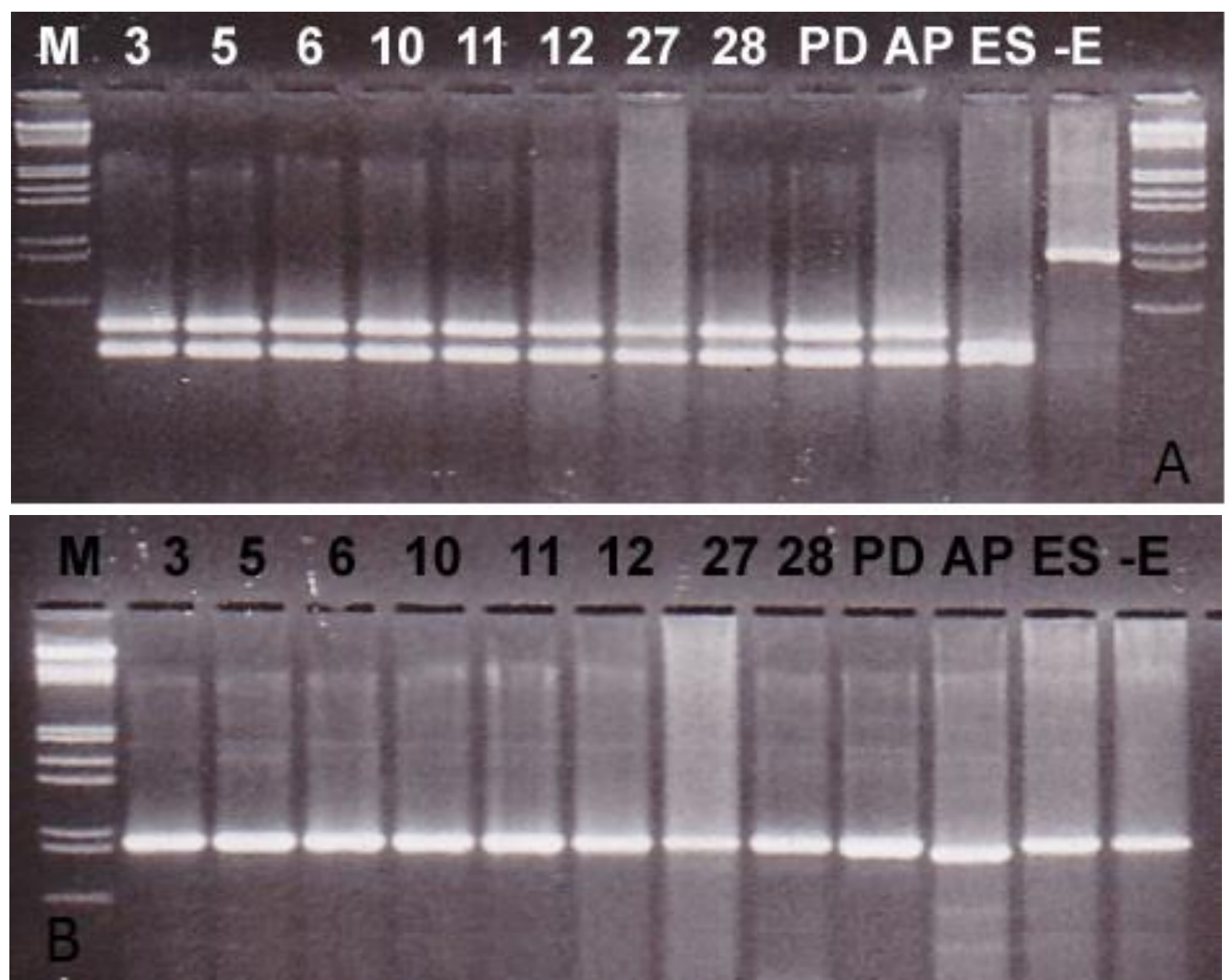

Figure 1. RFLP profiles of fU5/rU3 amplicons of different pear tissues using Rsal (A) Sspl (B) restriction enzymes. M: Marker (MBI Fermentas), 3: Flower 5: Fruit columella 6 and 10: Shoot 11and12: Leaf midribs 27 and 28: Root samples PD: 'Ca. Phytoplasma pyri' AP: 'Ca. Phytoplasma mali' ES: 'Ca. Phytoplasma prunorum' as positive controls -E: positive control without enzyme 


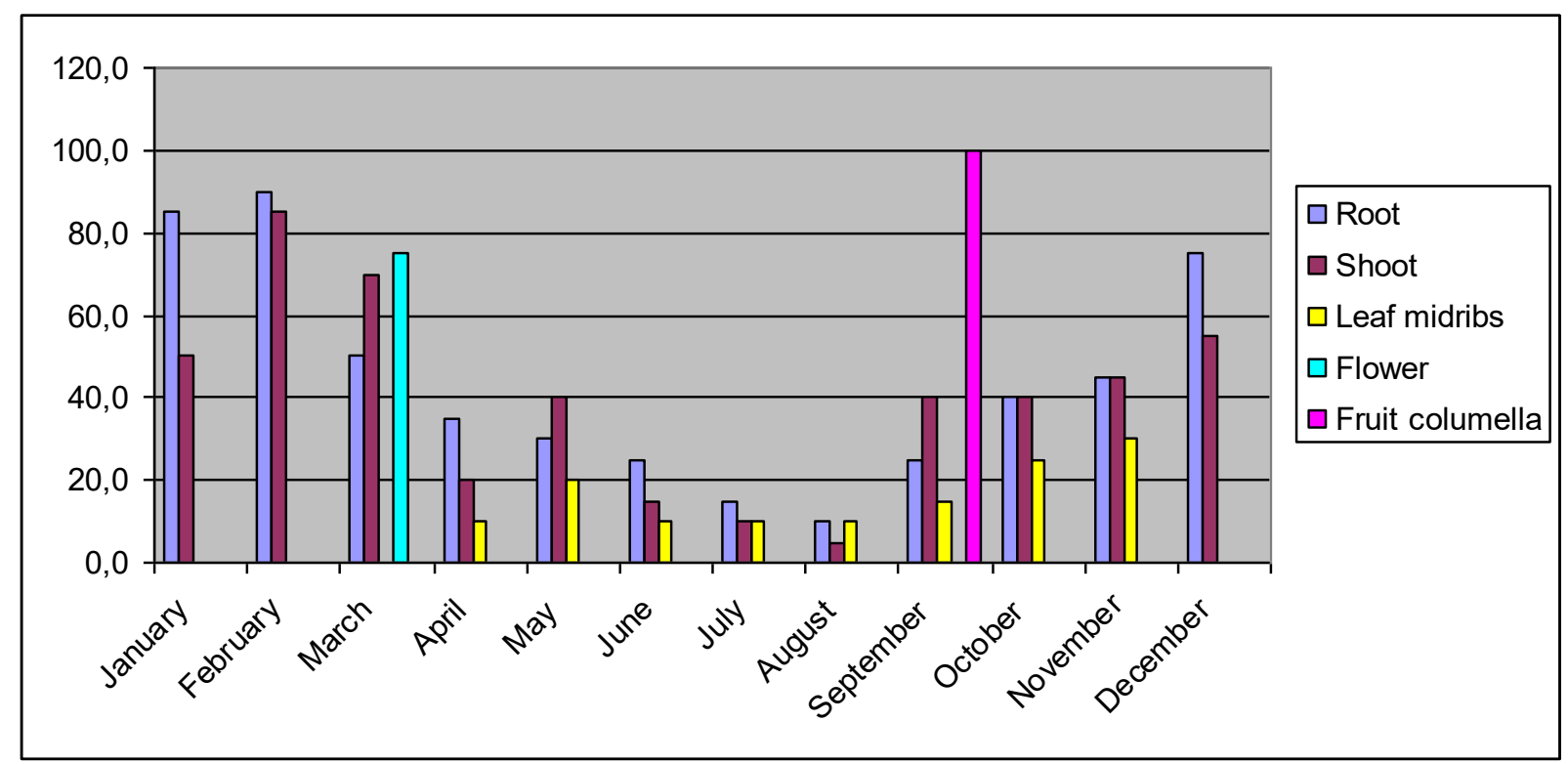

Figure 2. Average detection rates of ' $\mathrm{Ca}$. Phytoplasma pyri' in different pear tissues collected all year around from two different orchards in Bursa province of Turkey

Because of irregular distribution and low concentration of 'Ca. P. pyri' in pear trees, there are some difficulties to detect it throughout the year (Seemüller et al., 1984). Due to ' $C a$. P. pyri' is a quarantine pathogen in many countries, to find the most reliable plant tissues and the best season for routine diagnosis is reasonably important. The results obtained in this study indicated that this phytoplasma can be detected using nested-PCR analyses all over the year, depending on the sampling tissues and time. In two tested orchards, the best detection time for PD were found in winter (December, January, February) and early spring (March) for root and shoot samples. PD could be detected in shoot samples whole year around except July and August. These results confirm the previous reports published by Errea et al., 2002; Garcia-Chapa et al., 2003; Kucerova et al., 2007. The fruit columella and flowers can be used very succesfully for detection of ' $\mathrm{Ca}$. P. pyri' during the fruit ripening and flowering period, respectively. Among all tested samples columella is the only tissue that allows $100 \%$ detection rate of ' $\mathrm{C}$. P. pyri' in the fruit ripening period. According to our knowledge this is the first report to show fruit columella and flowers as a good inoculum source for detection of ' $\mathrm{C}$. . P. pyri'. Previous studies on seasonal variations for detection of Ca. P. pyri in pear trees showed that this phytoplasma disappear from the above-ground parts of the trees due to low winter temperatures and the pathogen survive in the roots of the scion to recolonize the stem and branches in the following spring (Seemüller et al., 1984). The data obtained in this study showed that PD phytoplasma can be detected in shoots even during winter season. Differences between two studies could be attributed to climatic and cultivar differences. As Garcia-Chapa et al. (2003) mentioned that Mediterranean conditions might allow circulation of ' $\mathrm{Ca}$. P. pyri' in the aerial parts of the tree for longer period than in central European climates. They also revealed that different cultivars response in a different way for phytoplasma detection. In their experiment cv. Blanquilla had the lowest detection rate in all samplings due to the most tolerant cultivar to disease comparing to cvs. Bartlett and Limonera. In this study due to one local cultivar (cv. Deveci) which has been found very sensitive to PD (Gazel et al., 2007) was used, the phytoplasma might be detected in many plant tissues all year around due to sensitiveness of this cultivar. This study confirms the importance of sampling period and tissues for the detection of PD phytoplasma in certification and quarantine programmes. 
Table 1. Monthly detection of 'Ca. Phytoplasma pyri' by nested PCR using universal primer pairs P1/P7 and fU5/rU3 in 20 infected pear trees 'Deveci' in two different orchards in Bursa-Turkey

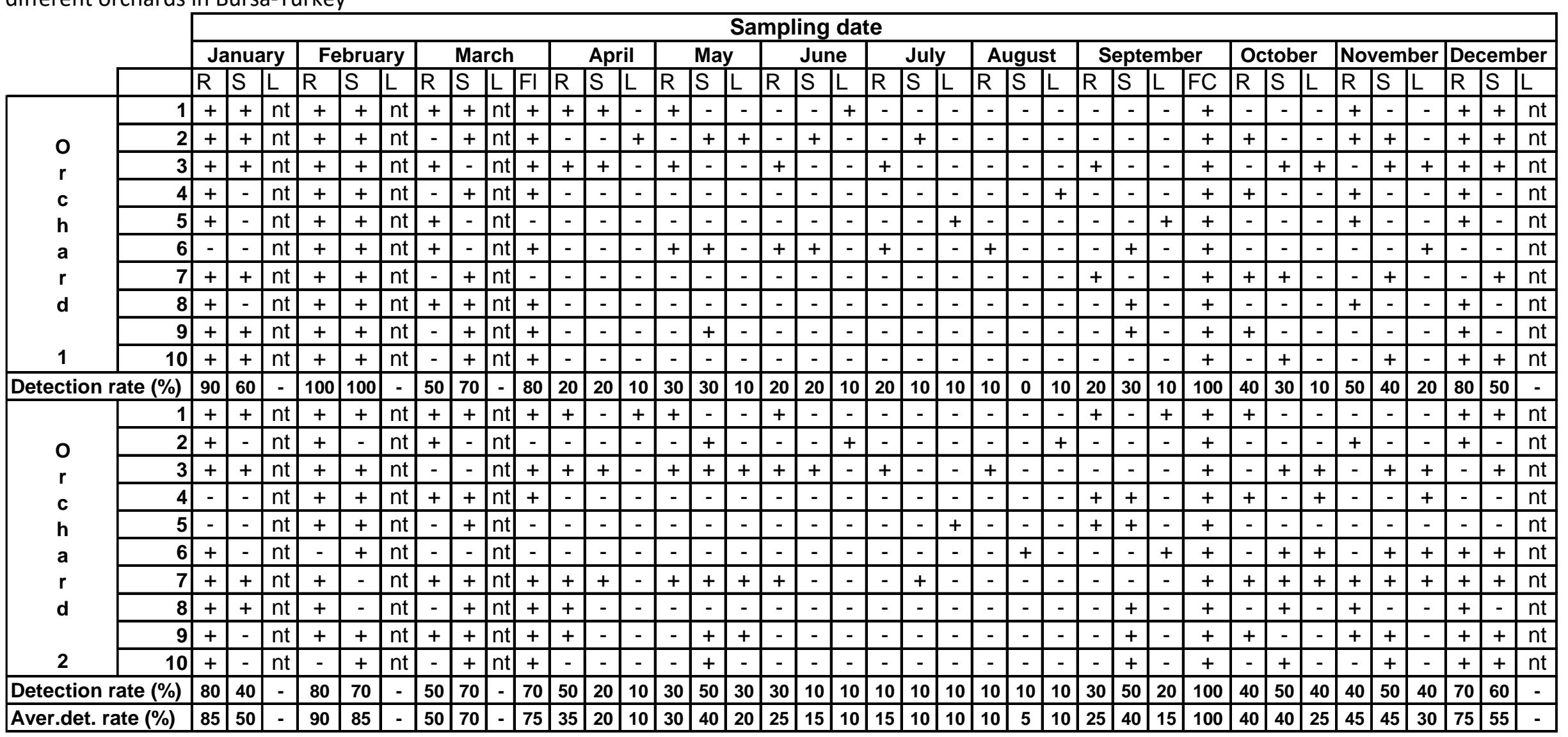

A tree was considered positive when only one type of plant tissue (R: root; S: Shoot; L: leaf midribs, Fl: flower; FC: fruit columella) was positive for PD.

nt: Not tested because of non-availability of leaves at that months. 


\section{ÖZET}

Amaç: Bu çalışmada, ülkemizde Bursa ilinde saptanmış olan armut yıkım fitoplazması ('Candidatus Phytoplasma pyri', PD) ile enfekteli 20 armut ağacı (Deveci çeşidi) seçilerek etmenin teşhis edilmesinde en uygun örnekleme zamanı ve bitki dokusunun belirlenmesi amaçlanmıştır.

Yöntem ve Bulgular: Yaprak, sürgün ve kök dokularında yıl boyunca örnekleme yapılırken çiçek dokuları Mart ayı, meyve dokuları ise Eylül ayında olmak üzere yılda bir kez testlenmiştir. Tüm örnekler P1/P7 ve fU5/rU3 üniversal primer çiftleri kullanılarak nested-PCR yöntemiyle analiz edilmiştir. Nested-PCR ürünleri $R s a l$ ve $S s p l$ restriksiyon enzimleri ile kesime tabi tutulmuştur. Elde edilen sonuçlara göre farklı bitki dokularında 'Ca. P. pyri 'nin saptanma oranının büyük ölçüde örnek toplama peryoduna bağlı olduğunu ortaya koymuştur. Bursa ili koşullarında Deveci armut çeşidinin olgunlaşma dönemine göre sadece Eylül ayında örneklenen meyve dokularınde yüksek oranda ' $\mathrm{Ca}$. P. pyri' tespit edilirken (\% 100), bunu çiçek dokuları (\%75) izlemiştir. Kök, sürgün ve yapraklarda ortalama tespit oranı sırasıyla \% 43.75, 39.58 ve 16.25 olarak bulunmuştur. Elde edilen sonuçlar armut ağaçlarında ' $C a$ P. pyri' nin saptanması için en iyi bitki dokularının meyve kolumellası ve çiçek olduğunu göstermiştir. Bu fitoplazmanın kök dokulardaki en yüksek tespit oranı Kasım-Mart ayları arasında bulunurken, ülkemizde sürgün örneklerinde yaz ayları hariç bütün yıl tespit edilebildiği belirlenmiştir.

Genel Yorum: 'Candidatus Phytoplasma pyri'nin testlenmesi için mevsimsel açıdan bir sınırlama olmaması durumunda en uygun dokular meyve ve çiçekler olup yıl boyunca testleme yapılması söz konusu olduğunda ise sırasıyla en uygun dokular kök, sürgünlerin floem ve kambiyum tabakası ve yapraklar olarak belirlenmiştir.

Çalışmanın Önemi ve Etkisi: Farklı armut dokularında 'Candidatus Phytoplasma pyri' varlığının mevsimsel dağııımı konusunda yapılan bu çalışma ülkemizde ilk kez yapılmıştır. Elde edilen veriler, Türkiye'de armut ağaçlarında sertifikasyon-karantina programları için ve armut yıkım fitoplazmasının etmeni Ca. P. pyri'nin moleküler tespiti konusunda önemli bilgiler sağlamıştır.

Anahtar Kelimeler: Armut, çiçek, meyve, sürgün, kök, fitoplazma, PCR-RFLP.

\section{ACKNOWLEDGEMENTS}

This study was supported financially by The Scientific and Technical Research Council (TUBITAK, TOVAG 1090014) of Turkey.

\section{CONFLICT OF INTEREST}

The authors declare no conflict of interest for this study.

\section{AUTHOR'S CONTRIBUTIONS}

The contribution of the authors is equal.

\section{REFERENCES}

Ahrens U, Seemüller E (1992) Detection of plant pathogenic mycoplasmalike organisms by a polymerase chain reaction that amplifies a sequence of the 16S rRNA gene. Phytopathology 82: 828-832.

Bertaccini A, Carraro L, Davies D, Laimer DC, Machado M, Martini M, Paltrinieri S, Seemüller E (2000) Micropropagation of a collection of phytoplasma strains in periwinkle and other host plants p. 101. In: 13th International Congress of IOM 14-19 July Fukuoka Japan.

Canik D, Ertunç F (2007) Ankara ve Yalova illerindeki Armut Bahçelerinde Görülen Pear Decline Fitoplazma Enfeksiyonunun Moleküler Karakterizasyonu. II. Bitki Koruma Kongresi Isparta s.108.

Çağlayan K, Ulubaş Serçe C, Gazel M (2006) A Preliminary Account of the Presence of Pear Decline Disease ('Candidatus Phytoplasma pyri') in Marmara Region of Turkey. XXth International Symposium on Virus and Virus-like Diseases of Temperate Fruit Crops \& XI th International Symposium of Small Fruit Virus Diseases Antalya 22-26 May 2006. p.123.

Deng S, Hiruki C (1991) Amplification of 16S rRNA genes from culturable and non culturable mollicutes. J. Microbiol. Methods 14: 53-61.

Errea P, Aguelo V, Hormaza JI (2002) Seasonal variations in detection and transmission of pear decline phytoplasma. J. Phytopathol. 150: 439-443.

Garci-Chapa M, Medina V, Viruel MA, Lavina A, Batlle A (2003) Seasonal detection of pear decline phytoplasma by nested PCR in different pear cultivars. Plant Pathol. 52: 513-520.

Gazel M, Ulubaş Serçe Ç, Çağlayan K, Öztürk H (2007) Detection of 'Candidatus Phytoplasma pyri' in Turkey. Bull. Insectology 60: 125-126.

Kucerova J, Kaserova R, Navratil M, Valova P (2007) Seasonal occurrence of 'Candidatus Phytoplasma pyri' in pear trees in the Czech Republic. Bull. Insectology 60:263-264.

Lorenz KH, Schneider B, Ahrens U, Seemuller E (1995) Detection apple proliferation and pear decline phytoplasmas by PCR amplification of ribosomal and non ribosomal DNA. Phytopathology 85: 771-776. 
Nemeth M (1986) Virus mycoplasma and rickettsia diseases of fruit trees. Martinus Nijhoff Publishers Budapest Hungary.

OEPP/EPPO (2007) Pear decline phytoplasma. EPPO A2 list of pests recommended for regulation as quarantine pests. No.95 Version 2007-09.

Prince JP, Davis RE, Wolf TK, Lee IM, Mogen BD, Dally EL, Bertaccini A, Credi R, Barba M (1993) Molecular detection of diverse mycoplasmalike organisms (MLOs) associated with grapevine yellows and their classification with aster yellows X-disease and elm yellows MLOs. Phytopathology 83: 1130-1137.

Seemuller E, Lorenz KH, Lauer U (1998) Pear Decline resistance in Pyrus communis rootstocks and progenies of wild and ornamental Pyrus taxa. Acta Hortic. 472: 681-690.

Seemüller E (1989) Pear decline: In: Virus and Virus-like Diseases of Pome fruits and simulating non-infectious disorders Fridlund P.R. (ed.) Washington State University Press Pullman W.A. pp.188-201.
Seemüller E, Schaper U, Zimbelman E (1984) Seasonal variation in the colonization patterns of mycoplasmalike organisms associated with apple proliferation and pear decline. J. Plant Dis. Protect. 91: 371-382.

Seemüller E, Schneider B (2004) 'Candidatus Phytoplasma mali', 'Candidatus Phytoplasma pyri' and 'Candidatus Phytoplasma prunorum' the causal agents of apple proliferation pear decline and European stone fruit yellows respectively. Int. J. Syst. Evol. Micr. 54: 1217-1226.

Smart CD, Schneider B, Blomquist CL, Guerra L, Harrison $\mathrm{NA}$, Ahrens $\mathrm{U}$, Lorenz KH, Seemuller E, Kirkpatrick BC (1996) Phytoplasma-specific PCR primers based on sequences of 16S-23S rRNA spacer region. Appl. Environ. Microbiol. 62: 2988-2993.

Ulubaş Serçe C, Gazel M, Caglayan K, Baş M, Son L (2006) Phytoplasma diseases of fruit trees in germplasm and commercial orchards in Turkey. J. Plant Pathol. 88: 175-181. 